\title{
Referate
}

Opsommings van referate gelewer tydens die Afdeling Biologie van die Suid-Afrikaanse Akademie vir Wetenskap en Kuns se jaarkongres, 17 en 18 Junie 1997, Potchefstroomse Universiteil vir CHO. (Die nacm van die aanbieder verskyn in veddruk.)

\section{Visparasiete - indikators vir metaalbesoedeling?}

\author{
A. Avenant-Oldewage \\ Departement Dierkunde, Randse Afrikaanse Universiteit, Posbus 524, Aucklandpark, 2006
}

\begin{abstract}
Waterbesoedeling is wêreldwyd toenemend belangrik. In dic verlede is daar uitsluitlik van chemiese analises gebruik gemaak om dic alard en omvang van dic problecm te bepaal, maar dic beperkte sukses met hierdic benadering het waterbestuurders genoop om ook alternatiewe metodes te oorweeg. Biologiese monitering is een metode wat ondersock word. Die voordele van biologiese toetsing is onder meer dat dit langtermyn- sowel as chroniese toestande reflekteer, terwyl monitering van watergehalte slegs akkuraat is ten tyde van dic toetsing en ook net op die plek waar die toetsing plaasvind. Waterkwaliteitstoetsing is voorts baie duur en hoogs opgeleide mannekrag is nodig om die toetse uit te voer. In die verband is ' $n$ visgesond-
\end{abstract}

heidsindeks vir moontlike gebruik, getoets. Drie visspesies in twee lokaliteite in die Olifantsrivier is bestudeer. Mierdie rivier hel 'n geskiedenis van besoedeling. Waterk waliteit, gesondheidsindeksindikators, melaalakkumulasie en die verskeidenheid en getalle van parasiete is bepaal.

Die resultate het getoon dat dic gesondheidstocstand van dic visse negaticl beinvloed word deur swak omgewingstoestande. Die parasietlading en verskeidenheid is ook beïnvloed deur dic omgewing. In minder besocdelde omgewings florecr ektoparasietc, terwyl endoparasicte meer algemeen in besoedelde omgewings voorgekom het. Dit mag moontlik wees om hierdie verskynsel as ' $n$ indikator vir besoedelingstoestande te gebruik.

\section{$L$-karnitien-detoksifisering verantwoordelik vir gedeeltelike beskerming teen ernstige neurologiese afwykings}

\author{
S. Jooste, E. Erasmus en L.J. Mienic \\ Departement Biochemic en Mikrobiologie, Potchefstroomse Universitcit vir Christelike Hoër Onderwys, \\ Potchefstroom, 2520
}

3-Meticlglutakonsuururic (3-MGA) is 'n aangebore melaboliese defek wat geklassifiseer word in vier kliniese sindrome. Tipe I is tans die enigste vorm van hierdie defek waarvan die werklike ensiemdefek bekend is en word gekarakteriseer deur vertraagde spraakontwikkeling (nie teenwoordig in dié geval nie). Pasiënte met hierdic defek het 'n abnormale 3-meticlglutakonic]koënsiem A hidratase (EC 4.2.1.18)-aktiwiteit. Dić ensiem is spesifick betrokke by dic Icusienkatabolisme. Baic van dic geakkumulecrde metabolicte, sowel as dic sckondêre metabolicte wat as gevolg van die defek gevorm word, is toksies vir die liggaam. Die ander drie sindrome (lipe II-IV) manifesteer met 'n verskeidenheid $k$ liniese en metaboliese profiele.

'n Kliniese verbetering van 'n pasiënt met 3-MGA tipe I na $L$-karnitienaanvulling het die motivering verskaf om dic metaboliese basis vir die verbetering te ondersock deur middel van elektrosproei-massaspektrometric (ESI-MS/MS).

$L$-karnitien is bekend vir die rol wat dic verbinding speel by dic oordrag van langkettingvetsure oor dic mitochondriale membraan vir B-oksidasic. ' $n$ Ander belangrike lunksie is die detoksifisering van geakkumuleerde metaboliete as gevolg van 'n ensiemdefek.

Tydens $L$-karnitienaanvulling het die pasiënt-E.V.R. klinies merkwaardig verbeter (voedingsprobleme en slaaploosheid is oorkom en die lewervergroting van $6 \mathrm{~cm}$ het heeltemal opgeklaar). Deurdat karnitien met toksiese asiel-KoA's gekonjugeer hel, is hierdie metaboliete uit die mitochondria verwyder en uitgeskei in die uriene as die ooreenstemmende karnitienkonjugatc (byvoorbecld 3-hidroksic-isovalcriclkarnitien: 7,45 mmol/ mol kreatinien, kontrole - I, 10; glutariclkarnitien: $3,7 \mathrm{mmol} /$ mol kreatinien, kontrole $0 ; 3$-meticlglutariclkarnitien, 7,5 mmol/ mol kreatinien, kontrole 1,33). In die proses is die asiel-KoA/ KoA-verhouding herstel. Die werklike meganisme van die toksiese metabolicte op neurologiese vlak is nie bekend nic. Dit is egter duidelik dat $L$-karnitien gedecltelik beskerming bied teen ernstige neurologiese afwykings, aangesien slegs milde afwykings by dic pasiënt teenwoordig is (sy woon 'n spesiale skool by). 


\title{
Analise van die vinnige chlorofil a-fluoressensie-styging (O.JP), as maatstaf van die invloed van die tabakmosaïekvirus op die funksie en struktuur van fotosisteem II in Nicotiana tabacum $\mathrm{L}$.
}

\author{
D. Lemmer en L. van Rensburg \\ Navorsingsinstituut vir Hervestigingsekologic, Potchefstroomse Universiteit vir CHO, Potchefstroom, 2520 \\ G.H.J. Krüger \\ Departement Plant- en Bodemwetenskappe, Potchefstroomse Universitcit vir CHO, Potchefstroom, 2520 \\ R.J. Strasser \\ Laboratoire de Bioénergetique, Université de Genève, Station de Botanicjue, Genève, Switserland
}

Die JIP-toets is gečvalueer as stresindikator vir die ontogenetiese ontwikkeling van sistemiese infeksie deur dic tabakmosaïk virus (TMV). Die JIP-tocts is 'n nuwe metode waarvolgens biofisiese vergelykings, afgelei van die vinnige-lase-chlorofil a fluoressensic-induksiekromme, aangewend word vir die bestudering van PSII-struktuur en -funksic. Dit is gebaseer op die J-pick van dic OJIP-kromme, wat verkry word deur gebruik te maak van 'n fluorometcr met 'n tydresolusic van $10 \mu \mathrm{s} \mathrm{en} \mathrm{'n} \mathrm{hoê} \mathrm{inten-}$ sitcil aktiniese ligbron. Veldprocwe is uitgevoer met dic tabakteellyn Potbar wat natuurlik met TMV geïnfekıcer is. Dic 17uoressensiemetings is weekliks uitgevocr op blaar 7 ( $m e t$ blaar 5 en 6 wat alreeds simptome getoon het) van geïnfektecrde sowel as gesonde kontroleplante tydens 'n volle grociscisoen. Gedurende week 1 hel daar geen sigbare simplome op blaar 7 voorgekom nic. Tydens week 2 was 'n ligte mosä̈ekpatroon teenwoordig wat len volle ontwikkel het in duidelik warneembare donkergroen cilandjics, omring deur liggroen areas in die daaropvolgende week. Dic JIP-tocts het duidelik aangetoon dat TMV PSII-aktiwiteit op 'n baie vroeë stadium, wannecr nog geen simptome visueel waarneembaar was nie, beinvloed. By dic geïnfektecrde plante het die energievloede, absorpsic per reaksiesentrum (ABS/RC), cksilonvangs per reaksiesentrum $\left(\mathrm{TR}_{0} / \mathrm{RC}\right)$ en clektrontransport per reaksiesentrum $\left(\mathrm{ET}_{/} / \mathrm{RC}\right)$ gedurende week 1 'n toename getoon. Die tocname in antennagroolte by dic geïnfekıcerde plante (tocname in ABS/RC) is dic gevolg van dic deaktivering van RC's, soos bevestig deur die afname in akticwe RC's per cenheidsblaaroppervlak (RC/CS).
Die deaktivering van RC's kan gesien word as 'n vroeê aanpassingsgereguleerde respons om skade te beperk. Die nicfunksioncle RC's beskik oor dic vermoë om 'n oormaal cksiteringsenergie te verk wis om sodoende die oorblywende aktiewe RC's te beskerm. Die maksimum kwantumopbrengs van fotochemic, $A B S / T R_{O}\left(\Phi_{p o}\right)$ van die geïnicklecrde plante, het 'n afname gedurende week 1 getoon. Hicruit kon afgelei word dat TMV lei lol die verlaagde eksilonvangsvermoë van sy gashecr. $\Phi_{(\mathrm{EO})}$ (ET,/ABS) verteenwoordig die moontlikheid dat 'n geabsor-

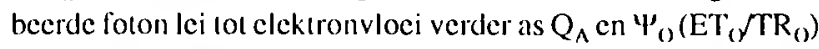
verteenwoordig dic moontlikheid dat ' $n$ reeds gevangde cksiton wel verder as $Q_{A}$ heweeg. Gedurende week 1 het beide $\Phi_{1: 0} \mathrm{en}$ $\left.\Psi_{(}\right)$'n afname by die geinfekteerde plante getoon. waruit algelei kon word dal die elektronoordragingsvermoë lacr is as gevolg van 'n kombinasic van verlaagde eksitonvangsvermoč. asook verliese aan reeds gevangde eksitone binne die elektronoordragingsisteem. Hierdic toestand mag dirck tot foto-inhibisie Ici. Dit stem ooreen mel literatuur wat meld dat TMV-simptoomuitdrukking direk in verband staan met ' $n$ verhoogde vatbaarheid vir lolo-inhibisic. Die geïnlekteerde plante se kwantumopbrengs en die spesilieke lunksionele paramelers (per RC) het op 'n periode van aanpassing tydens weke dric tot vyf gedui. Dic JIPtocts kon dus met welslae aangewend word om die rol van PSIl as redoksscnsor, vir dic regulering van konformasic- en funksionele veranderinge op RC-vlak, in reaksic op TMV-infeksie, te bestudecr.

\section{'n Alternatiewe metode vir die voorsiening van respireerbare lug in ondergrondse reddingskamers}

\author{
J.M. Venter, V.L. Hamilton-Altwell en H. Schalkwyk \\ Navorsings- en Ontwikkelingsłaboratorium, Naschem, Privaat sak X1254, Potchelstroom, 2520
}

Ondergrondse reddingskamers vorm 'n integrale deel van die reddings- en ontsnapstrategiec̈ in myne. In hierdie strategie vorm die voorsiening van respireerbare lug in reddingskamers een van dic belangrike komponente. Met dic voorsiening van respirecrbare lug word hedocl die toevoeging van suurstof aan en die verwydering van koolstofdioksied uit die reddingskameratmosfeer. ' $n$ Konsep is ontwikkel waardeur suurstof uit 'n vastestof-suurstolbron (suurstolkers) vrygestel en koolstoldioksied deur middel van adsorpsic verwyder word.

Die docl van dic ondersoek was om te bewys dat 'n vastestol- suurstofbron en koolstofdioksied-adsorpsic as alternatief kan dien vir die voorsiening van respireerbare lug.

Hierdie ondersock is in twec opeenvolgende fases in 'n funksionele ondergrondse reddingskamer uitgevoer. Tydens fase 1, wat as proel gedien het, is 24 persone vir 'n tydperk van 24 uur deur bogenoemde konsep van respireerbare lug voorsien. Tydens fase 2, dic kontrolefase, is dic opbou van metabolies geproduseerde koolstofdioksied oor 'n lydperk van I uur bepaal. Geen koolstofdioksiedadsorpsie het gedurende hierdic lase plaasgevind nic. 
Gedurende die 24 uur beselting van die reddlingskamer, het die 24 proefpersone 'n gemiddelde suurstol verbruik van 28 liter/ uur/persoon gehad. Dit het tot gevolg gehad dat 16368 liter suurstof aangevul moes word. Dit is teweeggebring deur clke 4 uur 'n suurstolkers te aktivecr wat \pm 3000 liter suurstof vrystel. Dic vrystelling van suurstof uit hicrdic 5 suurstolkerse het meegebring dat die suurstofvlak in dic reddingskamerat mosfeer aan die einde van die 24 uur-periode steeds bokant $20 \%$ was.

Teoreties is bereken, en dit is tydens dic kontrolefase bevestig, dat dic koolstofdioksiedkonsentrasic tydens besetting met
0,25\% per uur in die reddingskamer sou styg. Die werklike koolstoldioksiedkonsentrasic aan die cinde van dic 24 uurproefperiode was slegs $0,51 \%$, wat beteken dat in tolaal \pm 12615 liter koolstoflioksied deur middel van die adsorpsieproses verwyder is.

Hicrdic ondersoek het bewys dat dic konsep van 'il vastestofsuurstolbron en koolstoldioksicdadsorpsic voldoende respireerbare lug in reddingskamers kan voorsien. Hierdic konsep kan dus as alternatief dien om redelingskamers van respirecrbare lug te voorsien.

\title{
Menslikesperm-zona pellucida-binding, spermmotiliteit en seminaleplasma- $\mu$-glukosidase-aktiwiteit: 'n voorlopige studie
}

\author{
C. Huyser, E. Pienaar en S. du Precz \\ Reprodukticwe Biologic Laboratorium, Departement Obstetric en Ginckologic, Universitcil van Pretoria, Pretoria, 0002 \\ M.H. Fouric \\ Reprodukticwe Biologic Laboratorium, Departement Urologie, Universiteit van Pretoria, Pretoria, 0002
}

\begin{abstract}
Epididimale maturasic van sperme beïnvloed beide spermmotiliteit en die vermoë van sperme om die zona pellucida (ZP) te herken en daaraan te bind. Sperm-ZP-binding kan as 'n aanduiding van die effektiwiteit van spermfunksic beskou word. Seminale plasma- $\propto$-glukosidase-aktiwiteil ('n aanduiding van epididimale patensie) is gedurende sperm-ZP-binding geimpliseer.

Dic ondersoek is gedoen om dic interverwantskap tussen seminaleplasma (SP)- $\propto$-glukosidasc-aktiwiteit, spermmotiliteit en sperm-ZP-binding te bepaal. Dic seminale plasma en sperme van 18 semenmonsters $(n=18$ pasiënte) is verkry. Dic motiliteit van sperme (in semen) is deur middei van 'n rekenaarsistecm geanaliseer en epididimale spesifieke $\propto$-glukosidase-aktiwiteit in SP is spektrolotometries bepaal. Deur van kadawer-oösietc ( $n=7$ oösicte per semenmonster) gebruik te mak, is die hemizonatoets uitgevoer. Earl se gebalansecrde soutoplossing gesupplementecr met $10 \%$ vroulike serum, is by een groep hemizonas (kontrole) gevoeg en $1 \%$ SP tesame met $10 \%$ vroulike serum is by die tweede groep hemizonas (toets) gevoeg. Die spermkonsentrasie is aangepas na 50000 sperme per hemizona, waarna ko-inkubasic vir vicr ure uitgevoer is. Dic gemiddelde ouderdom van pasiënte was 32,3 jaar (24 tot 38 jaar) en dic gemiddelde normale spermmorfologic was $3,54 \%(0,0$ tot $8,5 \%)$. Dic
\end{abstract}

afsnypunt van $60 \mathrm{mE} / \mathrm{cjakulaat}$ vir $\propto$-glukosidase, dui op 'n betekenisvol lacr gemiddelde hemizona-indeks (HZI) en $\propto$ glukosidase-aktiwiteit in dic groep $<60 \mathrm{mE} / \mathrm{cjakulaat}$, teenoor dic groep $>60 \mathrm{mE} / \mathrm{cjakulaat}$ (HZI: 240,8 vs. 452,9, $p=0,0007$; $\propto$-glukosidase: 36,4 vs. $136,4, p=0,0149$ ). Betekenisvolle negatiewe korrelasies tussen $\propto$-glukosidase-aktiwiteit en spermmotiliteitsparamelers is verkry: (A) kurviliniêre snelheid (VCL: $p=$ 0,$0156 ; r=-0,6308$ ), (B) reguillyn-snelheid (VSL: $p=0,0320$; $r=-0,5736)$, (C) produk van kurviliniêre snelheid en gemiddelde maksimale amplitude van laterale kopbeweging (DANCE: $p=$ $0,0138 ; r=-0,6396)$. Hicrdic voorlopige resultate dui daarop dat hoë seminale $\propto$-glukosidase-aktiwiteit verband hou met hoë HZI-waardes en ook relaticf sterk gekorreleer is met lae VCL, VSL en DANCE (wat dui op spermhiperaktivering). Daar word dus gepostulecr dat spermhiperaktivering sperm-ZP-binding meer effektief bevorder as gocie progressicwe motiliteit van sperme. Die positiewe verwantskap tussen seminale $\propto$-glukosidase-aktiwiteit en sperm-ZP-binding (met dic supplementasic van 1\% SP), dui daarop dat: (A) 'n Positiewe invlocd van gocie epididimale funksie op sperm-ZP-binding voorkom; (B) Verbindings in SP betrokke mag wees tydens sperm-ZP-interaksic.

\section{Differensiële witbloedseltellings as 'n indikator van metaalbesoedeling}

\author{
I. Barnhoorn en J.H.J. van Vuren \\ Departement Dierkunde, Randse Afrikaanse Universitcit, Posbus 524, Aucklandpark, 2006
}

Visse is in noue kontak met hul eksterne omgewing. Enige verandering in die omgewing kan versteurings in die fisiese $\mathrm{en}$ chemiese komponente in dic bloed van vis veroorsalak. Die veran- dering in dic omgewing word deur besocdelstowwe soos metalc en chemicse stowwe veroorsak. In die natuur kom metale in spoorkonsentrasies voor, maar as gevolg van die snelle industriële 
groei en ontwikkeling, asook die gebruik van metale, het die konsentrasies kriticke vlakke in die omgewing bereik. In vorige navorsing is dit reeds bewys dat verskillende metale 'n elfek op die getalle van die verskillende soorte witbloedselie in blootgestelde visse het. Die verskillende soorte witbloedselle in vis reageer op verskillende besoedelstowwe en daarom kan dic dillerensiële witbloedseltellings gebruik word as 'n belangrike element in die diagnosering van ongemaksiluasies wat deur' 'n besocdelstof veroorsaak word tydens blootstelling daaraan. Oreochromis mossambicus is aan niedodelike konsentrasies mangatan in 'n cksperimentele deurvloeisisteem blootgestel vir onderskeidelik
96 uur (akuut) en 28 dac (kronies) in water mel 'n temperatuur van $23 \pm 1{ }^{\circ} \mathrm{C}$. Die resultate verkry het heduidende veranderende walardes $\left(P^{\prime}<0,05\right)$ in die differensiële withloedscllellings geloon. Limfopenia en leukositose is normale reaksies in 'n vis se liggaam teen inteksies van vreemde stowwe soos melaalione. In die navorsing is gevind dat niedodelike hoevec lhede mangalan dic imuunsisteme van vis onderdruk en sodoende die vis se verdedigingsmeganisme teen patogene wat teenwoordig kan wees, verlaag. Die variasie verkry in die getalle van die verskillende tipes wibloedselle kan dus gebruik worl in die waarneming van ongemak by visse tydens metalbesoedeling.

\title{
Ko-inkubasie van sperme en zona pellucida in die teenwoordigheid van seminale plasma: 'n voorlopige studie
}

\author{
S. du Preez, C. Huyser en P.F. Levay \\ Reproduktiewe Biologic Laboratorium, Departement Obstetric en Ginekologic, Universiteit van Pretoria, Pretoria, (0)(2
}

Suksesvolle bevrugting is onder andere athanklik van die vermoë van sperme om dic zona pellucida (ZP) te herken en daaraan te bind. Deur middel van die hemizonatoets kan supplemente wat sperm-ZP-binding bevorder, getoets word. Vorige hemizonistudies het daarop gedui dat teenstrydige resultate verkry is met dic byvoeging van seminale plasma (SP), indien dic herkoms van sperme en SP verskil. Die studic is onderneem om dic invloed van 'n lac konsentrasie seminale plasma op die spermZP-binding te bepaal indien sperme en SP van diesellde pasiënt verkry is. Agt semenmonsters van pasiente wat infertiliteitsbehandeling ondergaan, is onderwerp an die hemizonatoets. Die getoetste hemizonac is gesupplementeer met een persent SP en tien persent vroulike serum, terwyl die hemizonas van dic kontrolegroep slegs met vroulike serum gesupplementeer is. Na inkubasic is die hemizonas gespoel en 'n dubbel blinde telling van die aantal sperme per hemizona gebind, is deur twee individue uitgevoer. Die resultate verkry tydens hicrdie studic toon 'n betekenisvolle stimulasie $(p<0,000)$ ) van die persentasie sperm-ZP-binding in die teenwoordigheid van een persent seminale plasma. Die bevindinge van hierdie studic toon dat indien sperme en SP van dieselfde oorsprong is, 'n lac seminaleplasma-konsentrasic nic 'n nadelige invloed op spermZP-binding het nic. Verdere studies met betrekking tot die invloed van verskillende SP-modulecrders op sperm-ZP-binding, is egter nodig om kontroversiële resultate hicrilingalande te verklaar.

\section{Genetiese variasie in die bloedproteïene van 19 skaaprasse van Suid-Afrika}

\author{
J. Sargent en F.H. van der Bank
}

Departement Dicrkunde, Randse Afrikaanse Universiteil, Posbus 524, Auklandpark, 2006

A. Kolze

Diereverbeteringsinstituut, Privaat sak X2, Irene, 1675

Die hoeveclheid allosiemvariasic en die mate van genetiese differensiasic tussen 19 skaaprasse van Suid-Afrika is bepaal. Ses genetiesc bloedsisteme, wat algemeen gebruik word om tussen diererasse te onderskei, is bestudeer. Tussen $55 \mathrm{en} 66,67 \%$ van die proteienkoderende lokusse was polimorlies (95\% kriteria) in al dic rasse, behalwe dic Namaquat-ras wat minder polimorfies $(33,33 \%)$ was. Waardes van 1,67 $\mathrm{tol} 2,5$ is verkry vir die gemiddelde anantal allele per lokus, en die gemiddelde heterosigositeit per lokus is bereken as 16,6 tot $35,9 \%$. Dic alleliese samestelling vir die verskillende rasse het veral by die transferrien(TF)-lokus gevarieer. Onder andere was die TF-H-allecl uitsluitlik by die Dormer-ras waargeneem en dic TF-G-alleel net by die Afrino-, Van Rooy-, Borderlcis-, Swartkoppersië- en Skiler-ras. Die enigste polimorliese rasse by dic albumienlokus was die Suid-A frikaanse Vleismerinoen Van Rooy-ras. By die ander polimorliese lokusse was dic alleliese samestelling soortgelyk. Die alleclfrekwensies van dic SuidAfrikaanse Merino verskil van Merinorasse in ander lande by die TF-lokus. Genetiese afstandwaardes was die kleinste lussen the Dorper- en Dormer-, en Pnoff- en Romenol-ras en die grootste tussen die Romenof- en Swartkoppersië-ras. Die gemiddelde genetiese alstand tussen die 19 rasse was 0,067. Die FST is bereken as 0,123 vir polimorfiese lokusse, wat 'n duidelike indikasie is van minimale genetiese differensiasie tussen die rasse wat bestudeer is. Die resultate van hierdie studic kan in teelprogramme gebruik word en is dic ecrste genetiese studie van Suid-Afrikaanse skaaprasse. 


\title{
Karnitien-palmitoïeltransferase I-aktiwiteitsbepaling in fibro- blaste en leukosiete met die gebruik van elektrosproei-massa- spektrometrie
}

\author{
L. Nolte, F.H. van der Westhuizen, P.J. Pretorius en E. Erasmus \\ Departement Biochemic en Mikrobiologic, Potchelstroomsc Universitcit vir Christelike Hoër Onderwys, \\ Potchefstroom, 2520
}

\begin{abstract}
Karnitien-palmitoïeltransferase I (CPT I) is een van die belangrike ensieme wat met normale mitochondriale transport van sekere metabolicte geassosicer word. Die belangrikheid van die ensiem in normale energieproduksie word goed geillustreer gedurende vastende toestande, wanneer'n groot vloei van langkettingvetsure oor die mitochondriale membraan getransportecr moct word om B-oksidasic tc ondergaan. Tot op hede is CPT Iaktiwiteit in verskeie wecfsels getoets, insluitende lewer, leukosicte, plaatjics en fibroblaste, deur middel van dic isotoopuitruilings- voorwaartse toets, waarvolgens die tempo van palmitoïel-L-[metiel- $\left.{ }^{3} \mathrm{H}\right]$ karnitien-vorming vanaf palmitoïcl-KoA en $\mathrm{L}-\left[\right.$ metiel- $\left.{ }^{3} \mathrm{H}\right] \mathrm{karnitien}$ gemeet word. 'n Metode is ontwikkel wat die vorming van palmitoïelkarnitien vanal palmitoïcl-KoA en karnitien meet, wat die gebruik van radioaktiewe isotope uitskakel. Hiervoor word clektrosproci-massaspektrometric (ESI-MS/MS) en stabiele isotoopverdunning gebruik vir die kwantifisering van die gevormde produk. In die toetsmetode
\end{abstract}

word die tydafhanklike omskakeling van vrye karnitien deur CPT I na palmitoïclkarnitien kwantitatief gemeet, relatiel' tot die interne standaard, deur die skandering vir die moeder-ione van fragment 85 . Die spesifieke aktiwiteit van CPT I wat volgens hierdie metode in fibroblaste en leukosiete waargeneem is, vergelyk goed met die aktiwiteit bepaal Jeur die isotoopgebasecrde metode. Niespesificke akliwiteit met gebruik van die isoloopgebaseerde metode was $51 \%$ en $58 \%$ van die CPT Iaktiwiteit in fibroblaste en lcukosicte respekticwelik, terwyl dit $18 \%$ en $13 \%$ was met dic gebruik van elektrosproci-massaspektrometric. 'n Klein hoeveelheid van $0,1 \mathrm{mg}$ proteïene is genocgsaam vir die tocts. 'n Geringe aktiwiteit van $8,6 \%-9,6 \%$ was met malonicl-KoA-inhibisic van dic CPT I-ensiem waarnecmbaar. Die hoë sensitiwiteit, hoë sein-tot-geraasverhoudings en koste-cliektiwiteit van die ESI-MS/MS-metode maak dit ' $n$ ideale tegniek vir die meting van CPT I-aktiwiteit.

\section{Die rol wat natuurlik geïnfekteerde knaagdiere in die epidemiologie en transmissie van bilharzia speel}

\author{
G.J.J. Loubser, C.T. Wolmarans en K.N. de Kock \\ Bilharzia Studiegroep, Departement Dierkunde, Potchef'stroomse Universitcit vir CHO, Potchefstroom, 2520
}

Schistosomiase moet tans, hetsy as siekte of 'n infeksie, as Suid-
Afrika se mees verwaarloosde en onderskatte gesondheidsrisiko
beskou word. Dit is 'n siekte wat deur' $n$ wurmparasiet veroor-
saak en deur' $n$ slaktussengasheer versprei word. Die lewensiklus
van die parasiet word deur die mens as finale gasheer onderhou
en Bulinius africantus en Biomphalaria pfeufferi as slaktussen-
gasheer gedra. Die rol wat alternatiewe gashere in die onder-
houding van die siklus speel, is deur die Wêreldgesondheids-
organisasie as 'n leemte in kennis aangaande die siekte uitgewys
en dit is deel van die motivering vir die huidige studie. Dit is
bekend dat knaagdiere die parasiet suksesvol kan dra, maar in
sekere gevalle word daar nielewensvatbare eiers uitgeskei.
Die studie is in die Letsitele-gebied van die Noordelike
Provinsie gedoen. Vyftig Sherman-muisvalle is in geskikte habi- tal gestel en twee keer per dag besoek vir die verwydering van klein soogdiere en om die aas te vervang. 'n Mengsel van gerolde hawermout, olie en grondboonbotter is as aas gebruik. Tydens dic loodsstudic is daar vier verskillende spesies soogdiere versamel: Mastomys natalensis, Crocidura hirla, Crocidura spesic en Lemniscomys rosalia. Van hierdie vier spesies het slegs Mastomys natalensis lewende eiers uitgeskei. Die rol wat klein soogdiere kan speel om die siklus in die afwesigheid van besmette mense te onderhou, word tans verder ondersoek in bilharzia endemiesc gebiede van die Noordelike Provinsie. Daar is gevind dat Mastomys natalensis baie algemeen in die gebied voorkom, suksesvol die parasiet dra, lewensvatbare ciers uitskei en sodoende ' $n$ rol kan speel in die epidemiologic van bilharzia. 


\title{
Biochemiese genetiese merkers om hibriede tussen Synodontis zambezensis Peters, 1852 en S. nigromaculatus Boulenger, Mochokidae 1905 uit te ken
}

\author{
E. Bruwer, F.H. van der Bank en G.H. Steyn \\ Departement Dierkunde, Randse Alrikaanse Universiteit, Posbus 524, Aucklandpark, 2006
}

\begin{abstract}
As gevolg van dic ongekontrolecrde translokasic van varswatervisse van suidelike Afrika kan hibriede nadelige implikasies hê. 'n Biochemiese genetiese studie van hibriede tussen Synodontis zambezensis vanaf Suid-Afrika en S. nigromaculatis vanaf Namibie is uitgevoer om vas te stel of bovermelde hibriede kan oorleef en of genetiese merkers gevind kan word om dit te identiliseer. Allosiemvariasic is ondersoek deur horistontale styseljelelcktroforese te gebruik. Elektroloreticse ontleding van die lokusse is op spier-, bloed-en lewermonsters gedoen en 'n
\end{abstract}

genetiese merker is vir die peplidase C2 ensiemkoderende lokus gevind deur gebruik tc maak van leosien-liroksien as substrat. Die hibriede toon intermediêre allecnmobiliteite I.o.v. dić van die suiwer spesies. Hierdie resultaat is van kardinale belang omdat dit nou moontlik is om hibriede te identifisecr deur roetinemonitering. Sodanige hibriede kan onomkecrbare verandering aan plaaslike geenpocle veroorsaak asook an dic bewaring van inheemse biodiversiteit en moet onmiddellik verwyder word waar dit voorkom.

\section{Die invloed van follikulêrevog-gesupplementeerde medium op menslikesperm-zona pellucida-binding}

\author{
P.F. Levay, C. Huyser en F. Ic R. Fourie
}

Reprodukticwe Biologic Laboratorium, Departement Obstetric en Ginckologie, Universitcit van Pretoria, Pretoria, 0001

Menslike follikulêre vog (FV) kom gedurende bevrugting in groot hoeveclhede om die kumulusselle van die oösiel voor. Sperme is dus blootgestel aan noemenswaardige FV-konsentrasies alvorens sperme in vivo aan die zona pellucida (ZP) bind.

Met hicrdie ondersock is die invloed van verskillende konsentrasies FV-gesupplementecrde medium op menslikespermZP-binding bepaal. Menslike ovaria, verkry vanal kadawers, is geaspireer vir zona-intaktc oösicte. Dic hemizonatoets is gebruik om die invloed van $1 \%, 10 \%, 50 \%$ sowel as $50 \%$ hitlegeïnakliveerde FV-supplementasic van Earle se gebalanseerde soutoplossing op die sperm-ZP-binding, te bepaal. Dic hemizonatoets is uitgevoer met sperme van 'n bewese lerticle donor. Dic spermkonsentrasic is aangepas na 50000 sperme per hemizona, waarna ko-inkubasic vir 4 ure uitgevoer is. Die hemizonas is geêvalueer en die aantal sperme aan die kontrole en cksperimentele hemizonas ( $n \geq 7$ hemizonas per supplement), sowel as die hemizona-indeks is hepaal. Die invloed van $10 \%$
FV-supplementasie op vier verskillende donorspermmonsters, is ook ondersock. Die volgende is bevind:

1. Die 1\% FV en die $50 \%$ hiltegeinakliveerde FV-supplemenlasie het geen betekenisvolle invloed op die sperm-ZP-binding getoon nic $(p>0,05)$.

2. Tien persent FV-supplementasic het 'n belekenisvolle verhoging $(\approx 50 \%)$ in sperm-ZP-binding $(p=0,0284)$ uitgelok.

3. Die $50 \%$ FV-supplement het die sperm-ZP-binding betekenisvol geïnhibeer $(p=0,0077)$. Dit is 'n verlaging van $\approx 35 \%$.

4. Tien persent FV-supplementasie het in al vier donorspermmonsters die sperm-ZP-binding verhoog.

Die resultate toon 'n duidelike bifasiese invloed van verskillende FV-konsentrasies op sperm-ZP-binding. Supplementering met $10 \% \mathrm{FV}$ het gelei tot 'n duidelike verhoging in sperm-ZP-binding en kan as behandelingsmodus gedurende geassistecrde reproduksie gebruik word.

\section{Vermeerdering van Pterocarpus angolensis DC. en evaluering van die potensiële anti-bakteriese werking van kiaatsap}

\author{
K. van der Riet en G.H.J. Krüger \\ Departement Plant- en Bodemwetenskappe, Potchefstroomse Universitcit vir CHO, Potchefstroom, 2520 \\ L. van Rensburg en R. De Sousa Correia \\ Navorsingsinstituut vir Hervestigingsekologie, Potchef'stroomse Universiteit vir CHO, Potchefstroom, 2520
}

Ten spyte van hul bedreigde status word kiaat-bome (Pterocarpus angolensis) steeds in hul natuurlike habitat as brandhout versamel, asook vir ekstraksie van sap vir medisinale gebruik. Die tweeledige doel van dié ondersock was om vas te stel wat 
die mees koste-ellektiewe en optimale wyse vir dic vermecrdering van die bome sou kon wees en om te bepalal of die tradisionele gebruik van kiaalsap as antibakteriese midclel geregverdig is. Saad, steggies $(0,5$ tot $2,5 \mathrm{~cm}$ in deursnec en 25 tot $30 \mathrm{~cm}$ in lengte) en stoklote $(3$ tot $12 \mathrm{~cm}$ in deursnee en 90 tot $120 \mathrm{~cm}$ in lengte) is as potensiële vermeerderingswyses geěvalueer. Nadat dic saad uil die vrugliggame verwyder is, is dit vir Iwec uur in koue water gedompel en vervolgens toegelaat om in gesterilisecrle sand by temperature wal gewissel het tussen $10 \mathrm{en} 40$ " $\mathrm{C}$ te kiem. Dic prosedure is tydens verskillende tye van die jaar herhaal en daar is bevind dat die hoogste kiemingspersentasie gedurende September behaal is. Ten spyte daarvan dat die gemiddelde kiemingspersentasie van die saad slegs $9,6 \%$ ( $n=1116$ sade) was, het dic saailinge ' $n$ gemiddelde hoogte van $12 \mathrm{~cm}$ reeds na slegs 60 dae bereik. $45,6 \%$ van dic sade wat nie gekiem het nic, was te wyte an fungusinfeksie. Dit blyk dus dat fungusinfeksic 'n belangrike rol specl by kicmkragtigheid. Van dic 192 steggies wat met dic hormoon (4indool botter-/asynsuur) behandel is en onder gekontrolecrde toestande ontwikkel het, het gemiddeld $27 \%$ aktiewe groei vertoon, teenoor die $21,6 \%(n=240)$ van die steggies wat geen hormoonbchandeling ontvang het nie en onder natuurlike klimatologiese omstandighede ontwikkel het. In beide gevalle was $95 \%$ van die steggies steeds lewens na 'n periode van 60 dae. $\mathrm{Na} 90$ dac het $26 \%$ van die stoklote wat horisontaal $(5 \mathrm{~cm}$ onder dic oppervlak) aangeplant is, knoppe gevorm wat in lengte tussen $1 \mathrm{cn} 30 \mathrm{~mm}$ gewissel het. In 'n poging om 'n verklaring te vind vir die lae kiemingspersentasie, is saad van 475 volwasse vrugte, wat vanal dic bome versamel is, verwyder. Slegs $10,1 \%$ van hierdic sade het gesond voorgekom. Dic sade is vervolgens soos volg behandel: (i) droè hiltc (50 "C vir 10 min.), (ii) hormoonvoorbehandeling $\left(0,1 \mathrm{mM} \mathrm{GA}_{3}\right.$ vir 24 uur in dic donker), (iii) geen voorbchandeling. Dic behandelde sade is toegelaat om onder die volgende temperatuutkondisies te ontkiem: (i) 'n konstante temperatuur van $20^{\circ} \mathrm{C}$, (ii) wisselende temperaluur van 20 tot $30^{\circ} \mathrm{C}$, (iii) wisselende lemperaluur van 10 tot $40^{\circ} \mathrm{C}$. Dic hoogste kiemingspersentasic is by dic wisselende kiemingstemperatuur van $10 \operatorname{tol} 40$ " $\mathrm{C}$ waargeneem (20\%, 20\% en $60 \%$ vir dic hormoon-, hilte- en geen voorbehandeling respek(iewelik). Geen bevestiging kon verkry word van die antibakteriese werking van die kiaatsap toe dit teen grampositiewe en gramnegatiewe prokariote, sowel as twee cukariote met dic agardiffusiemetode, getocts is nic.

\title{
Beheer van epifiete in 'n Gracilaria gracilis-Haliotes midae- akwakultuursisteem
}

\author{
P.D.R. van Heerden* en B.L. Robertson \\ Departement Plantkunde, Universiteit van Port Elizabeth, Port Elizabeth, 6000) \\ L. de Kock \\ Departement Dierkunde, Universiteit van Port Elizabeth, Port Elizabeth, 6000
}

\begin{abstract}
Epifiete is 'n groot problecm in tenkkulture van Gracilaria gracilis- en ander kommersiële seewiere, waar onnatuurlike grocitoestande die groei van epifiete bevorder. Verskeie chemiese metodes van epifietbeheer, insluitende koperchloriedbehandelings in damkulture van Gracilaria spp., is reeds met wisselende sukses gebruik. Die gebruik van koperchloried as 'n inhibecrder van epilicte in tenkkulture van $G$. gracilis is nog nie voorheen ondersock nie. Koper kan deur bindings met selwandpolisakkariedes in die weefsel van Gracilaria spp. akkumulecr. Koperbehandelde $G$. gracilis, wat as voedsel vir Haliotes midae (perlemoen) gebruik word, mag moontlike newe-effekte op hierdie diere tot gevolg hê. Die invloed van koperchloriedbehandelings op die inhibering van die epifiet Ectocarpus siliculosus in tenkkulture van G. gracilis (Stackhouse, Irvine en Farnham) by 'n perlemoenplaas (Marine Growers), is tydens hierdie studie geëvalueer.

Koperchloried is by koperkonsentrasies van 400 en $800 \mu \mathrm{gL}^{-1}$ $\mathrm{Cu}^{2+}$ in Iwee eksperimente vir onderskeidelik 'n enkele en twee opeenvolgende periodes van $48 \mathrm{~h}$ toegedien. In die tweede cksperiment was dic besmetting met E. siliculosus gering, en is die behandeling uitgevoer om $G$. gracilis se toleransic teen herhaalde koperbchandelings te ondersoek. Die spesificke grocitempo's van die G. gracilis-kulture en dic effek op $E$. siliculosus is vir vier weke na die onderskeic behandelings weekliks gemonitor. 'n Voedingseksperiment is uitgevoer om die effek van koperbehandelde G. gracilis-kulture op die grocitempo van $H$. midae te ondersoek.
\end{abstract}

Koperkonsentrasies van onderskeidelik $400 \mathrm{en} 800 \mathrm{gL}^{-1} \mathrm{Cu}^{2+}$ het die groci van E. siliculosus in die cerste eksperiment geimhibeer. Die elfektiefste inhibering is met 'n enkele $800 \mu \mathrm{gL}^{-1} \mathrm{Cu}^{2+}$ behandeling verkry. In beide eksperimente het genoemde koperkonsentrasies 'n af name in die spesifieke groeitempo van $G$. gracilis tot gevolg gehad. In die ecrste eksperiment het $G$. gracilis na drie weke volkome herstel, terwyl geen herstel in die tweede eksperiment verkry is nic. Drie weke na 'n enkele $400 \mu \mathrm{gL}^{-1} \mathrm{Cu}^{2+}$ behandeling, was dic grocitempo's van dic behandelde kulure hoër as die ooreenstemmende kontrole. Een geïsoleerde geval van inhibisic van $H$. midae-grocitempo's, dric maande na dic aanvang van die voedingseksperiment, met herstel 'n maand later, is aangetoon.

Die resultate toon positicwe implikasies vir die beheer van $E$. siliculosus-besmetting in tenkkulture van G. gracilis. 'n Hoë matc van sensiliwiteit van $G$. gracilis teenoor koperbchandelings is aangetoon. $\mathrm{Na}$ ' $n$ enkele $48 \mathrm{~h}$-koperbchandeling, was dic inhibisic van groeitempo's slegs tydelik, met langtermynstimulering vanweë verminderde gasheer-epifietinteraksies. Twee opeenvolgende koperbehandelings het langtermyngrocitempo-inhibisie tot gevolg gehad. Geen langtermyninhibisic van $I$. midac-grocitempo's is na vyf maande van voeding met koperbehandelde $G$. gracilis aangetoon nic. Kleinskaalse implementering van koperbehandelings by Marine Growers Perlemoenplaas toon belowende resultate vir die kostc-cffektiewe behecr van E. siliculosus.

Ons stel voor dat versigtige gebruik van koperbehandelings 'n elfekticwe metode van epilietbeheer op perlemoenplase en in ander akwakultuursisteme mag wees. 


\title{
Floristiese evaluering van drie gerehabiliteerde asdamme in die Hendrina-distrik
}

\author{
T.L. Morgenthal, S.S. Cilliers en K. Kellner \\ Departement Plant- en Bodemwetenskappe, Potchefstroomse Universiteit vir CHO, Potchelstroom, 2520) \\ H. van Hamburg \\ Departement Dierkunde, Potchefstroomse Universitcit vir CHO, Potchefstroom, 2520)
}

\begin{abstract}
Die ekologiese stabiliteit van industriële ckostelsels is van groot belang vanweë streng wetgewing en hoë finansiële koste verbonde alan die onderhoud daarvan. Die vernietiging en agteruitgang van natuurlike hulpbronne in en om industriee is ' $\mathrm{n}$ belangrike rede vir die evaluering en monitering van die ekologiese stabiliteit van sulke gebiede. Gerehabilitecrde asdamme vorm 'n groot komponent van industriële ckostelsels. Dit is noodsaaklik dat gerehabilitecrde gebiede estelies aanvaarbaar en ckologies selfonderhoubaar moet wees. Min inligting is egter beskikbaar aangaande faktore wat die stabiliteit van industrięc ckostelsels na rehabilitasie hepaal.

Hierdic studic maak decl uil van 'n multidissiplinêre studic wat die floristiese en faunistiese komponente en impakte op dric gerehabilitecrde asdamme in dic Hendrina-omgewing insluit. Tydens hierdic studie is die gemeenskapsdinamika ten opsigtc van ckologiese stabiliteit van plantgemeenskappe tussen natuurlike grasveld en asdasmme in verskillende stadiums van rehabilitasie, geëvalueer. Hierdic studie behels Braun-Blaunquetopnames in 63 releves, uitgeplaas in die studiegebied en in 'n aangrensende natuurlike grasveld. Data is met behulp van dic TWINSPAN-klassifisering en DCA-ordeningstegniek verwerk om ekologiese veranderlikes te vergelyk.
\end{abstract}

Uit die resultate blyk dit dat daar ten opsigte van plantspesic-

\begin{abstract}
samestelling duidelike verskille tussen die natuurlike veld en gerehabiliteerde gebiede bestan. Die dominante spesies in die natuurlike grasveld sluit onder meer Themeda riandra en Heleropogon contorfus in. Plantegroei van gerehabilitecrde gebiede is soortgelyk an dic plantegroei wat oorspronklik hervestig is. Die dominante spesies op gerehabilitecrde asdamme is Eragrostis curvula, Cynodon dactylon, en Cyperas esculenums. Uit die DCA-ordening is ses duidelike gemeenskappe geidentifiseer. Die gebied wat deur natuurlike plantegroci gekenmerk word, kan as een van hierdic gemeenskappe onderskei word. Vier ander gemeenskappe kom op reeds gerehabilitecrde asdamme voor. Een van hierdic plantgemeenskappe word geassosicer met terreine waar tuinalval gestort is, terwyl ander met onderskcidelik dic walle van asdamme, sypelsones en die oppervlak van die asdamme geassosicer word. Uil die analise is gevind dat dic alard van versteuring, byvoorbeeld faunisticse impakte en die stort van huishoudelike afval, verskille in behandeling, soos die saadmengselsamestelling en verskille tussen hellings en oppervlaktes die belangrikste laktore is wat die vestiging van verskillende plantgemeenskappe bepaal. 'n Duidelike verandering in plantgemeenskapsamestelling tussen nuut gerehabilitecrde en gerchabiliteerde areas ouer as drie jaar, kon watargeneem word.
\end{abstract}

\section{Die waarde van urienanalises in die raming van die voorkoms van urinêre bilharzia in 'n bepaalde gemeenskap}

\author{
K.N. de Kock, C.T. Wolmarans en G.J.J. Loubser \\ Departement Dierkunde, Potchefstroomse Universiteit vir Christelike Hoër Onderwys, Potchefstroom, 2520
}

Die voorkoms van skistosoomeiers met mirasidiums wat sigbare
beweging vertoon in 'n vars urienmonster, is tans nog die enigste
onfeilbare manier om 'n lewende infeksic van urinere bilharzia
by die mens te diagnoseer. Dit is 'n eenvoudige analise wat 'n
standaardprosedure by alle hospitaallaboratoriums in bilharzia
endemiese gebiede is. 'n Ondersock by 'n landelike hospitaal
in die endemiese gebied in die Noordelike Provinsic, het egter
aan die lig gebring dat 'n sekere minimum getal urienmonsters
vir mikroskopiese ondersock verwys moet word om 'n verant-
woordbare raming van die werklike getal besmette persone te
kan maak. 'n Analise van ses jaar se rekords van laboratorium-
analises by hierdie hospitaal het aangetoon dat ongeveer $25 \%$
van die pasiënte waarvan urienmonsters vir mikroskopiese
analise verwys is, positicf was vir bilharzia. Dit verteenwoordig

egter' 'n voorkomssyfer van hoogstens $2,3 \%$ positicwe gevalle uil die gemiddeld 50000 persone per jaar wat die afgelope ses jaar as buitepasiênte aangemeld het. 'n Gevallestudic wat by dieselfde hospitaal uitgevoer is, waartydens urienmonsters van alle persone wat oor 'n bepaalde tydperk by buitepasiente aangemeld het, mikroskopies ondersock is, het egter getoon dat dic besmettingspersentasie tussen 10 en 15\% kan wees. 'n Belangrike implikasie hicrvan is dat betckenisvolle getalle persone wat om ander redes as bilharziaverwante simptome, by buitepasiëntafdelings aanmeld, egter ook met bilharzia besmet kan wees maar nie as sodanig gediagnosecr word nic. Dit kan daarloc aanleiding gec dat 'n raming van bilharziavoorkoms wat op amptelike hospitaalrekords gebaseer is, tot 'n belangrike onderskatting kan lei. 


\title{
Fitoplanktonbevolkings in die Loch Vaal
}

\author{
L. Grobler en A.J.H. Pieterse \\ Departement Plant- en Bodemwetenskappe, Potchefstroomse Universiteit vir CHO, Potchefistroom, 2520
}

\begin{abstract}
Die Loch Vaal is 'n vlak, mensgemaakte meer, met 'n gemiddelde diepte van 1,5 metcr, in dic Rictspruit-opvanggebied wat ontstaan het na dic bou van dic Barrage in 1923 in dic Vaalrivicr. Vaalrivierwater wat deur die Barrage opgedam word, stoot in die Rietspruit op om die Loch Vaal te vorm. Dic Loch Vaal word intensief vir ontspannigsdocleindes soos visvang, swem en waterski gebruik. Decglike monitering van die waterkwaliteit van dic Loch Vaal is dus belangrik. Voedingstowwe word voortdurend vanaf die opvanggebied en die sedimente van die Loch Vaal na die oorliggende water vrygestel en goed deur die hele waterkolom vermeng a.g.v. die ontspanningsaktiwiteite op die meer. Dic hoë voedingstofinhoud en die lang retensietyd van water in dic Loch Vaal gee aanleiding tot opbloeic van bv. sentriese diatome, kryptofiete en blougroenalge. Cyanophyceac (blougroenalg)opblocic van veral Oscillatoria simplicissima, Anabaena circinale en Microcystis aeruginosa is kenmerkend in die somer. Blougroenalg-opbloeic is belangrik omdat dit lei tot estetics onaanvaarbare water, soos water met slegte reukc cn smake. Dit is veral belangrik omdat dic blougroenalgsclle toksienc kan afskei wat die gesondheid van mens en dier nadelig kan beïnvloed.

Watereksemplare is tweemaandeliks by vyf verskillende versamelpunte in die Loch Vaal versamel en by nog cen punt in dic Rietspruit net voordat dit in die Loch Vaal invloci. Fisiese en chemiese analises is deur Rand Water-personcel uitgevocr, terwyl die biologiese analises deur personecl van die Depar-
\end{abstract}

tement Plant- en Bodemwetenskappe, PU vir CHO uitgevoer is. Eksemplare wat vir algidentifiscring $\mathrm{en}$ - $k$ wantilisering gebruik is, is tydens versameling met $2 \%$-formaldehied gefiksecr. Algidentifisering en -kwantifisering is m.b.v. 'n omge kecrde ligmikroskoop gedoen deur dic gebruik van standaardmetodes.

Nege hoofalggroepe is in die Loch Vaal geïdentilisecr, nl. Cyanophyccac, Bacillariophyceac, Chlorophyceac, Cryptophyceac, Chrysophyceac, Dinophyceac en Euglenophyceac. Suksessie lussen die alggroepe word hoofsaaklik deur die volgende omgewingsveranderlikes geregulecr: temperatuur, $\mathrm{P})_{4}-\mathrm{P}$ en $\mathrm{SiO}_{2}$-Si. Dic Cyanophyceac kom hoofsaaklik in dic somer voor en bereik opblocigetalle vanaf Desember tot einde Maart. Dic blougroenalg, Microcystis acrigunosa, kom reg deur dic jaar in dic algbevolking voor $\mathrm{en} \mathrm{bereik} \mathrm{maksimum} \mathrm{getalle} \mathrm{in} \mathrm{dic} \mathrm{middel}$ van dic somermaande. Dic filamentagtige Cyanophyceac is net in die warm somermaande gevind en bereik opblocigetalle in dic laatsomermaande. Bacillariophyccac domineer die winteralgbevolking en bercik maksimum getalle by temperalure laer as $10{ }^{\circ} \mathrm{C}$. In 1996 (na die vloede) is daar egter gevind dat die Cryptophyceac dic algbevolking in die winter domineer by temperature bokant 10 "C. Dic Chlorophyceac (bercik maksimum getalle in die vroec̈ somer), Dinophyceac, Chrysophyceac en Euglenophyceac is regdeur die studieperiode in lae konsentrasies aangetref.

\section{Rekenaargesteunde onderrig in die lewenswetenskappe}

\author{
H. van Hamburg en J.M. le Roux \\ Departement Lewenswetenskap (UNISA), Potchefstroomse Universiteit vir CHO, Potchefstroom, 2520
}

Die optimale gebruik van hulpmiddels vir onderrig is veral relevant vir afstandonderrig, waar die moontlike negaticwe effekte van die fisicse afwesigheid van 'n dosent deur goeic studiemateriaal en hulpmiddels ondervang moet word. Die aanbicding van intensiewe praktiese modules, waartydens groot hoeveclhede mikroskooppreparate en ander biologiese materiaal binne 'n kort periode bestudeer moet word, asook die voorbereiding vir praktiese eksamens is vir afstandonderrig twee verdere probleemgebiede. Die koste van duur biologiese materiaal eskaleer weens die toenemende getal studente wat jaarliks vir biologiese modules inskryf. Hierdic probleme het gelei tot 'n spesifieke behoefte om digitale beelde van die studiemateriaal op rekenaar te versyfer. Elektroniese studiegidse, waar spesilieke woorde deur middel van hipcrteks aan die beclde gekoppel is, is saamgestel. 'n CD-ROM-gebaseerde rekenaarprogram is met sukses in dic Departement Lewenswetenskappe by UNISA, asook die PU vir CHO, geimplementecr. Hicrdic program het dit moontlik gemak om hoëgehalte-studente-ondersteuning aan groot grocpe studente te lewer, en meer tyd vir persoonlike aandag beskikbaar te stel, terwyl minder druk op dic studiemateriaal geplaas is. Die elcktroniese studiegidse kan op kompakte skywe (CD) na studiesentrums versprei word waar studente op hul eic tyd vir praktiese en teoretiese modules en cksamens kan voorberci.

\section{Spesiasie in Pollimyrus castelnaui (Boulenger, 1911)}

\author{
N.S. Flint en F.H. van der Bank \\ Departement Dierkunde, Randse Afrikaanse Universiteit, Posbus 524, Aucklandpark, 2006
}

Die orde Mormyriformes (Teleostei) is endemics aan Afrika, cn sluit ongeveer 188 spesies van die Mormyridac in. Hicrdie orde is buitengewoon omdat dic verskeic spesies almal bevocg is om swak clcktriese seine te genereer en te ontvang. Elcktriese scine 
word gebruik vir oriëntering, prooi- en roofdicropsporing, spesieherkenning en kommunikasic. Die elcktriese seine is spesicspesifick en 'n voorlopige studie van die scine van Pollimyrus castelnaui, wat van die Kwando-Linyanti-Chobe en dic boonste deel van die Zambesirivier-sisteme atkomstig is, het aangedui dat daar twee of drie onderskeie groepe binne die spesiegroep teenwoordig is. Dic onderskeic groepe het dalk ontstaan toe dic Zambesirivier gedurende 1952 lol in die Kwando-LinyantiChobe-rivier oorstroom het. Dit kon een van twee moontlike gevolge gehad het, naamlik introgressicwe hibridisasic of vermenging van die bevolkings mel min geenvloci. Dic tweede moontlikheid is meer waarskynlik, veral as die verlynde herkenningsmeganismes en grondgebied-beskermingsmeganismes van Pollimyrus castelnaui in gedagte gehou word. Dic hooldocl van dic projek is om dié resultate te ondersock met behulp van alloensiemontleding. Twee bevolkings is met ' $n$ intermediêre bevolking vergelyk om die graad van divergensic tussen hulle te bepaal. Dic metodologic behels dic ondersock van differensiasic met gebruik van allo-ensiemdata wat as uitstekend beskou word op die vlak van bevolkingsgenetika, aangesien dit die grootste biochemiese datastel vir organismes verteenwoordig. Weelsels is voorberei vir ontleding deur styseljel-elektrolorese wat aan beide aaneenlopende en afgebroke bufferstelsels blootgestel is. Die jelle is selcktief gekleur vir' 'n recks cnsicmstclscls. 'n Rekenaarprogram, BIOSYS-1, is gebruik om data met betrekking tot variasie binne en differensiasic tussen die bevolkings te genereer.

Uit die agt-en-twintig lokusse wat vertolkbare resultate gegee het, was net nege lokusse polimorfies in een of meer van die bevolkings. Dit gee 'n graad van polimorfisme van $32,1 \%$. Dic gemiddelde antal allele per lokus is $1,36(+0,13)$. Die meeste van die alleclfrekwensies hel mel die Hardy-Weinburgverhoudings ooreengestem. By nel vier van die lokusse (IDH-1, (iPI-1, LDH-1 en PEP-C) het verskuiwings plaasgevind. Die gemiddelde heterosigositeit per lokus was die minste by Linyanti $(0,071 \pm 0,026)$ en die meeste vir dic Zambesibevolking $(0,080 \pm$ $0,030)$. I lierdie waardes lê tussen 0 tot 0,083 vir ander spesies in die Zambesirivicr. Die walardes in hicrdie studic was ook soorlgelyk aan dié van Marcusenius macrolepidoms $(0,081) \mathrm{en}$ is clus aanvaarbaar vir mormyriform-visse. Die fiksasicwaarde, $F_{\mathrm{sr}}$, is bereken as 0,020 wat ' $\mathrm{n}$ duidelike indikasic van minimale genetiese differensiasie tussen die bevolkings is. Die onsydige genetiese al'stande, volgens Nei (1978), wissel tussen 0 en 0,002, Thorpe en Solé-Cava (1994) het 'n genetiese al'stand van minder as 0,3 aanbeveel vir visse van dieselfde spesie. Die groepering volgens Nei (1978) plaas die bevolkings van Kwando en Linyanti nader aan mekaar as aan dié van die Zambesi, met 'n kofenetiese korrelasie van $83,8 \%$, terwyl die Wagnerprosedure dic Linyantien Zambesibevolkings onderling groepeer met 'n kolenetiese korrelasic van $100 \%$. Laasgenoemde resultaal is meer aanvalarbaal as dic Zambesi se oorstroming in 1952 in aanmerking geneem word. Die lac fiksasicindeks, die gebrek aan vaste allecllrekwensieverskille en die klein geneliese afstande dui aan dat darar nog spesiasic, nog verbastering plaasgevind het. Daar is ( $\log$ ) bewyse van mikro-cvolusic wat plaasvind in elk van die bevolkings en wat met dic verloop van tyd tot spesiasie kan lei. Die inligting verkry sal nuttig wees in die voortgaande verbetering van dic mormyrid-klassifikasiesistecm, en vir dic bewaring en bestuur van hicrdie visse. Bovermelde resultate sal bevestig word met behulp van clektricse orgaanseine en DNA-volgordebepalings.

\title{
Isolering en karakterisering van keratinolitiese ensieme uit bakterieë
}

\author{
T. van Rooyen, T. Reinecke en P.J. Pretorius
}

Departement Biochemie en Mikrobiologie, Potchefstroomse Universiteit vir CHO, Potchefstroom, 2520

Die steeds groeiende pluimveebedryf het te kampe met dic probleem van afvalmateriaal in die vorm van dooie en afgekeurde diere en veral die groot hoeveelheid vere. Om van hierdie afval op 'n omgewingsvriendelike wyse ontslac te raak, kan 'n duur $\mathrm{cn}$ moeilik hanteerbare probleem wees. Vere en vecrmecl kan aangewend word vir bemesting en as proteïen-diectaanvuller weens die samestelling daarvan. Probleme met vertecrbaarhcid en gebrek aan aminosure soos tirosien, alanien, lisien en histidien, kan oorbrug word deur gebruik te mak van hidrolisering deur keratinolitiese bakterieë en veral die ensiem keratinase.
Agt keratinolitiese bakterieë is geisolecr vanal verskcic keratiensubstrate soos hoendervere, skaapwol en 'n lcerfabriek. Drie spesies is geidentifiseer, nl. Bacillus anthracis, B. cereus en Alcaligenes faecalis. Optimale grociloestande vir ensicmproduksic is vasgestel en strek vanaf 28 tot $37^{\prime \prime} \mathrm{C}$ en 'n pH van 6 tot 8 . Die keratinase-ensicme van drie van die isolate is gesuiwer. Optimale aktiwiteit vind plaas by ' $\mathrm{pH}$ van 8 en temperature van 28 tot $37^{\circ} \mathrm{C}$. Die molckulêre massa van $B$. cereus $\mathrm{J}$ en $A$. faecalis $\mathbf{l} \hat{\mathrm{c}}$ in dic omgewing van $45 \mathrm{kDa}$ en dic van $B$. cereus $\mathrm{O}$ in dic omgewing van $68 \mathrm{kDa}$

\section{Hematuria as indikasie van 'n urinêre bilharziase-besmetting}

\author{
C.T. Wolmarans, K.N. de Kock en G.J.J. Loubser \\ Departement Dierkunde, Potchefstroomse Universiteit vir CHO, Potchefstroom, 2520
}

Twee bilharziaparasietspesies word in Suid-Afrika aangetref, naamlik Schistosoma haematobitum wat aanleiding tot urinêre bilharziase gee en $S$. mansoni wat ingewandsbilharziase veroorsaak. Beide hicrdic parasiete produseer eiers wat van 'n 
stekel voorsien is en wat as identifikasiekenmerk gebruik word. llierdic stekel malak dit vil die cier moontlik om deur dic arteries waarin die wurms voortplant, te dring en so dic urienweë in dic geval van $S$. haematobiam en dic lumen van die intestinum in dic geval van $S$. mansoni te bereik. In gevalle van hoë besmeltings gaan perforering van die blocdvate normaalweg met die verskyning van bloed in die uriene en sloelgang gepaard. In hierdic ondersock is gekyk na dic moontlikheid om die verskynsel van hematuria (bloed in die uriene) as indikasie van urinêe billharzia le gebruik. Die uriene vall 6025 pasiëne van die l cetaba-hospitalal wat al mal verskiflende grade vall hematuria vertoon het, is tussen 1990 en 1995 met die hulp van laboraloriumtegnici vir die teenwoordigheid van $S$. haematobium-eiers ondersoek. Uit hierdic ondersock het dit alan die lig gekom dat hematuria wat vertecnwoordig word deur 100 rooiblocdselle en meer per $160 \mathrm{X}$ vergroling by bepalalde groepe van die bevolking, en onder bepaalde omstandighede, wel oor diagnostiese polensiaal beskik.

\title{
Die effek van wisselbou met soet witlupien (Lupinus albus) en monokultuur op die opbrengste van mielies, koring en lupien
}

\author{
J.A.M. van der Mey, J. Middel, J.F. Marec en G.A. van der Mey \\ LNR-Instituut vir Graangewasse, Privaat sak X1251, Potchefstroom, 2520
}

Die internasionale literatuur gec talle voorbeclde van die gunstige eflek van wisselbou met lupiene. Om vas te stel of hierdic effek ook met $L$. albus ten opsigte van mielies en koring onder Suid-Afrikaanse toestande bereik kan word, is in 1991 ' $n$ micliclupien-procf met 10 behandelings op Ermelo en 'n koring-lupienproct met sewe behandelings op Bethlehem geinisieer. In die vierde seisoen (1994/95) van die koring-lupien-proef' is 'n droogtestremming ondervind. Dic LKL-K-opbrengs was 1063 $\mathrm{kg} / \mathrm{ha}(117 \%)$ van dic koringmonokultuur $(911 \mathrm{~kg} / \mathrm{ha}=100 \%)$. Dic gemiddelde lupienopbrengs was $717 \mathrm{~kg} / \mathrm{ha}(79 \%)$, dić van die lupienmonokultuur $744 \mathrm{~kg} / \mathrm{ha}(83 \%)$. Dic vyfde seisoen ( $1995 /$ 96) was 'n seisoen met 'n hoë reënval $(800 \mathrm{~mm})$. Geen betckenisvolle verskille is in dic koringopbrengste gevind nic; t.w. $1278 \mathrm{~kg} / \mathrm{ha}$. Die gemiddelde lupienopbrengs was $2138 \mathrm{~kg} /$ ha. Dic beste opbrengs was in dic lupienmonokultuur $(2596 \mathrm{~kg} /$ ha); betekenisvol beter as die LKLK-L-bchandeling (2 $135 \mathrm{~kg} /$ ha), wat dic behandeling met dic swakste opbrengs was. Veral in dic miclic-lupien-procl was dic elfek op miclics as opvolggewas skouspclagtig in dic vierde seisoen (1994/95). Dic gemiddelde opbrengs van enige behandeling, waar lupien mielies vooralgegaan hel, was $3921 \mathrm{~kg} / \mathrm{ha}$ (130\%), die opbrengs van die mielicmonokultuur was $3009 \mathrm{~kg} / \mathrm{ha}(100 \%)$. Dic hoogste opbrengs van $4463 \mathrm{~kg} / \mathrm{ha}(149 \%)$ is in die MLL-M-behandeling verkry. Dic reënval vir die mielies was $535 \mathrm{~mm}$ en vir lupien $470 \mathrm{~mm}$. Daar was geen betekenisvolle verskil lussen die lupienbehandelings nie $(1189 \mathrm{~kg} / \mathrm{ha}=39,6 \%)$. Dic proef in dic vyfde seisoen $(1995 /$ 96) is beskadig deur hacl en gecn beickenisvolle verskille kon vasgestel word nic. Dic gemiddelde miclicopbrengs was 1870 $\mathrm{kg} / \mathrm{ha}$, die gemiddelde lupienopbrengs $1085 \mathrm{~kg} / \mathrm{ha}$. In geval van koring en miclics is na lupien ' $n$ tocname in proteieninhoud waargeneem. In koring is ook 'n toename in hektoliter massa gevind. Ofskoon in een seisoen 'n toename in mineralestikstol waargeneem is, was daar nog geen waarneembare tendens vir stikstof en nege ander chemiese ontledings nie. Hicrdie proewe gee reeds betckenisvolle aanwysings dat die monokultuur van koring en miclies 'n opbrengsverlaging tot gevolg het. By die monokultuur van lupien was dit nog nic die geval nic, moontlik omdat die stikstolbindende bakıcricè nog nic optimale vlakke bereik het nic.

\section{'n Ekologiese studie van die Loch Vaal}

\author{
A. Swanepoel en A.J.H. Pieterse \\ Departement Plant- en Bodemwetenskappe, Potchefstroomse Universiteit vir Christelike Hoër Onderwys, \\ Potchefstroom, 2520
}

Water wat deur die Barrage opgedam word, stoot in die Rietspruit op om die Loch Vaal te vorm. Die Loch Vaal is 'n klein, vlak, mensgemaakte meer wat op 'n omvangryke wyse vir ontspanningsdoeleindes aangewend word. Dic vlak en oop aard van dic Loch Vaal stimuleer alggroci, en opbloeic van blougroenalge is 'n algemene verskynsel in die Loch Vaal. Voedingstowwe vir alggroei (veral fosfaal) word deurlopend vanaf die bodemsedimente, asook vanaf die Rietspruit voorsien en dra tol dic eutrofetoestand van die Loch Vaal by.

In 'n poging om die omvang en gevolge van hierdic fosfaatverryking te bepaal, is die losfaatbelading via dic Rietspruit sedert 1987 bestudeer. 'n Verdere ondersock is geloods na die invlocd van dic hersirkulering van fosfaat vanaf dic bodemsedimente om vas te stel welkc van hierdie twee bronne die grootste voorsiener van losfaat in die Loch Vaal is. Met behulp van 'n laboratoriumopstclling is ook probecr vasstel of daar' $n$ verskil in fosfaatvrystclling vanaf die bodemsedimente onder acrobiese en anacrobiese toestande is.

Dic hoofbron van fosfaat in dic Loch Vaal blyk dic Rictspruit te wees, wat meer as $90 \mathrm{~kg} \mathrm{PO}$-P per dag tot die Loch Vaal bydra. Die bodemsedimente is ook (alhoewel in ' $n$ mindere mate) verantwoordelik vir dic fosfaatbelading in die Loch Vaal (gemiddeld 6,47 kg PO $4-\mathrm{P}$ per dag onder aerobiese en $26 \mathrm{~kg} \mathrm{PO}_{4}$ $P$ per dag onder anacrobiese (tocstande) oor sy totale oppervlak.

'n Vermindering van eksterne fosfaat, sowel as die inaktivering van sedimentfosfaat, behoort geïmplementecr tc word om hierdic vlak en oop mensgemaakte mecr, suksesvol tol 'n oligotrofe toestand te restoureer. 


\title{
Die respirasiefisiologie van die strandkrap Ocypode ceratophthalmus tydens 'n drafsessie op 'n trapmeul
}

\author{
W.J. van Aardt \\ Departement Dierkunde, Potchefstroomse Universiteit vir CHO, Potchel'stroom, 2520
}

\begin{abstract}
Strandkrappe gebruik hul kieuc vir ioon- en waterregulering en nie vir asemhaling nie. Hulle verdrink in secwater, want hulle is landdiere wat in lug asemhaal. Die "long"-area is 'n cen millimeter dun binnevoering van die kieu-kamer. Hierdic epitecl maak ongeveer $16 \%$ van die kieu-kamer se binne oppervlak uil. Om te tocts hoe effektief hierdie epiteel as long funksionecr, is die volgende eksperimente gedoen: Volwasse krappe is vir 20 minute by 'n spoed van $13,3 \mathrm{~cm}$ sekonde ${ }^{-1}$ laat draf. (Teen hierdic spoed kan die krappe vir twee uur draf voordat moegheid intree.) Die laktaatkonsentrasic in die hemolim het van $4,5 \mathrm{mmol} \mathrm{L}$ tot $20,7 \mathrm{mmol} \mathrm{L}^{-1}$ gestyg, terwyl die $\mathrm{pH}$ van die hemolimf van 7,91 tot 7,72 daal. Die suurstolverbruikskoers het van 'n rustende waarde van $3,5 \mathrm{mmol} \mathrm{L^{-1 }}$ tot ongeveer agt keer hoër, nl. $28,5 \mathrm{mmol} \mathrm{L}^{-1}$,gestyg. Dit neem 'n krap wat rus ongevecr 'n uur om sy suurstofverbruikskoers weer na die rustende vlakke te laat terugkeer. Die affiniteit van die hemosianien vir suurstof daal vanaf ' $\mathrm{n}$ P50 - waarde van $4,5 \mathrm{~mm} \mathrm{Hg}$ tot $10,0 \mathrm{~mm} \mathrm{Hg}$ wat moontlik aan die lae $\mathrm{pH}$ en meer I-laktaat in die hemolimf toegeskryf kan word.
\end{abstract}

\begin{abstract}
Hicrdic resultate dui daarop dat die gaswisscling van dic longepiteel nie so docltreffend is as wat dit byvoorbeeld by insekte is nic. Eksperimente is vervolgens uitgevoer waar die krappe mel 20 mikroliter radioaktiewe l-laktaat in die hemolim/ ingespuit is en dadelik op die trapmeul geplaas is om te draf. Daar is gevind dat die verskyning van radioaktiel gemerkte koolsuurgas in die uitgeasemde lug (afkomstig van dic $\mathrm{C} 14$ laktaat) via die Krebs-siklus na 20 minute reeds op 'n maksimale vlak is wat beteken dat gaswisseling, anders as dic bogenoemde eksperimente alandui, baic goed funksioneer. Volgens hierdic eksperiment en ook histologiese getuienis (uit die literatuur) kan dic gaswisselingsepiteel wel 'n ware long genocm word, hocwel dit nie die tipiese sponsagtige struktuur besit nie. 'n Gevolgtrekking wat met ons huidige kennis gemaak kan word, is dat 'n uiters doeltreffende ventilasiemeganisme in die kieuholte van die strandkrap aanwesig moet wees sodal dic ecn millimeter dik longepiteel altyd 'n steil gradiënt vir suurstof handhaat tussen die kieu-holte en die binnekant van die longepitecl. Hierdic hipotese behoort ondersoek te word.
\end{abstract}

\section{Die effek van temperatuur en fotoperiode op die ontwikkeling van Lupinus albus (L) onder gekontroleerde toestande}

\author{
R. Keeve en H.L. Loubser \\ LNR-Instituut vir Graangewasse, Privaat sak X1251, Potchefstroom, 2520 \\ G.H.J. Krüger \\ Departement Plant- en Bodemwetenskappe, Potchefstroomse Universiteit vir Christelike Hoër Onderwys, \\ Potchefstroom, 2520
}

\begin{abstract}
Lupiene is ' $n$ minder bekende gewas in die somerreënvalgebiede van Suid-Afrika. Daar is wêreldwyd baie min oor die invloed van fotoperiode en temperatuur op die groci en ontwikkeling van lupiene bekend. Die doel van die studie was om die effek van fotoperiode en temperatuur op die groei en ontwikkeling van die gewas te bepaal, sodat sinvoller kultivar- en plantdatumaanbevelings aan produsente gemaak kan word. 'n Eksperiment om die effek van temperatuur en fotoperiode in 'n klimakabinet te bepaal, is uitgevoer op drie Lupinus albuskultivars, nl. Tifwhite, Esta en Kiev, by twee temperature (10/ $20^{\circ} \mathrm{C}$ en $18 / 28^{\circ} \mathrm{C}$ ) en twee fotoperiodes (8 en 16 uur) in alle kombinasies. Dic helfte van die saad is vir 21 dae by 4 " $\mathrm{C}$ gevernalisecr om die verpligte kouebehoefte van Tifwhite te oorkom. Waarnemings is gemaak van die periode vanaf plant
\end{abstract}

tot opkoms, begin blom en duur van blom. Alle gevernaliscerde behandelings het vinniger ontwikkel as die ongevernaliseerde behandelings, selfs Esta en Kiev wat nie 'n verpligte kouebehoefte het nic. Die periode vanaf plant tot opkoms was korter by die hoër temperaluur. Alle kultivars het vinniger onder langer fotoperiode geblom as wat dic verwagte reaksie van langdagplante toon. Die duur van blompcriodes was in die geval van Esta en Kiev korter by die hoër temperatuur, in teenstelling met Tifwhite wat langer geblom het by die hoër temperatuur. Esta en Kiev hel ook ' $n$ korter periode geblom by die langer fotoperiode, maar Tifwhite se blomperiode was korter by die korter fotoperiode. Hierdie resultate dui op 'n sterk langdagreaksie by al dic kultivars. Die teenstrydige reaksie van Tifwhite is moontlik die geval van 'n sensitiwiteit vir hoë temperature. 